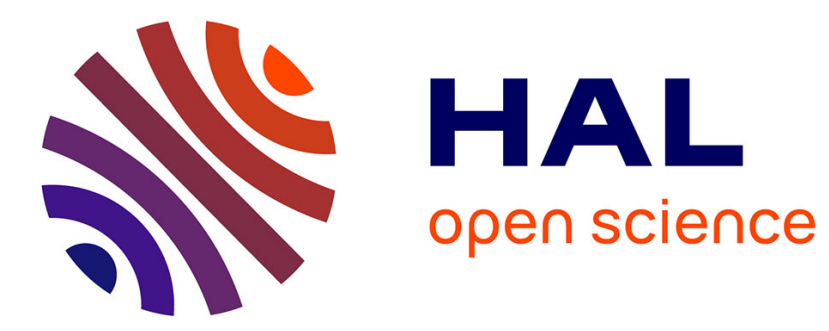

\title{
Prospects for repellent in pest control: current developments and future challenges
}

Emilie Deletre, Bertrand Schatz, Denis Bourguet, Fabrice Chandre, Livy Williams, Alain Ratnadass, Thibaud Martin

\section{- To cite this version:}

Emilie Deletre, Bertrand Schatz, Denis Bourguet, Fabrice Chandre, Livy Williams, et al.. Prospects for repellent in pest control: current developments and future challenges. Chemoecology, 2016, 26 (4), pp.127 - 142. 10.1007/s00049-016-0214-0 . hal-01608606

\section{HAL Id: hal-01608606 https://hal.science/hal-01608606}

Submitted on 12 Aug 2020

HAL is a multi-disciplinary open access archive for the deposit and dissemination of scientific research documents, whether they are published or not. The documents may come from teaching and research institutions in France or abroad, or from public or private research centers.
L'archive ouverte pluridisciplinaire HAL, est destinée au dépôt et à la diffusion de documents scientifiques de niveau recherche, publiés ou non, émanant des établissements d'enseignement et de recherche français ou étrangers, des laboratoires publics ou privés. 


\title{
Prospects for repellent in pest control: current developments and future challenges
}

\author{
Emilie Deletre ${ }^{1,2} \cdot$ Bertrand Schatz $^{3} \cdot$ Denis Bourguet $^{4} \cdot$ Fabrice Chandre $^{5}$. \\ Livy Williams ${ }^{6}$ - Alain Ratnadass ${ }^{1} \cdot$ Thibaud Martin $^{1,2}$
}

\begin{abstract}
The overall interest in environmentally safe pest control methods and the rise of insecticide resistance in pest populations have prompted medical and agricultural entomology research on insect repellents in recent years. However, conducting research on repellent is challenging for several reasons: (1) the different repellent phenomena are not well defined; (2) it is difficult to test for and quantify repellent; (3) the physiological mechanisms are poorly known; (4) the field efficacy appears to be highly variable. Here, we identified five different types of repellent: expellency, irritancy, deterrency, odor masking and visual masking, and described behavioral bioassays to differentiate between them. Although these categories are currently defined by their behavioral response to different stimuli, we suggest new definitions based on their mechanism of action. We put forward three main hypotheses on
\end{abstract}

Handling Editor: Michael Heethoff.

Emilie Deletre

emilie.deletre@cirad.fr

1 UR Hortsys, CIRAD, Campus de Baillarguet, 34398 Montpellier, France

2 Department plant health, ICIPE, Kasarani, 00100 Nairobi, Kenya

3 Centre d'Ecologie Fonctionnelle et Evolutive (CEFE) UMR 5175, CNRS-University of Montpellier, University Paul Valéry-EPHE, 1919 route de Mende, 34293 Montpellier, France

4 UMR CBGP, INRA-CIRAD-IRD-Montpellier SupAgro, Campus de Baillarguet, 34980 Montferrier, France

5 UMR MIVEGEC, IRD-CNRS-UM, 911 Ave Agropolis, 34394 Montpellier Cedex 5, France

6 USDA-ARS, European Biological Control Laboratory, Campus de Baillarguet, 34980 Montferrier, France the physiological mechanism: (1) a dose effect that modifies the behavior, (2) a repellent mechanism with specific receptors, or (3) inhibition of the transduction of neural information.

Keywords Deterrent - Antifeeding - Odorant receptor . Olfaction · Gustation - DEET · Pest management . Vector control

\section{Introduction}

The plant kingdom produces several hundred thousand chemical substances, which affect insect behavior (Fraenkel 1959). For instance, their secondary compounds are involved in the recognition and acceptability of plants by insects. The reception of host cues encompasses a wide variety of stimuli (olfactory, visual, tactile and gustatory) (Thorsteinson 1960), and host selection is believed to proceed in a hierarchical manner. The first step, 'choice', involves seeking and recognition of the host using olfactory and visual cues. It generally takes place over a distance. The second step, 'selection', is the acceptability of the host on the basis of gustatory cues (Visser 1988) and it generally takes place upon contact. A similar hierarchical sequence operates for insects feeding on human or animal hosts.

The overall interest of environmentally safe pest control methods and the increasing number of insecticide-resistant pest populations have recently prompted research on insect repellents in medical (including veterinary) and agricultural entomology. Hence, for the past decade, research on insect repellent increased steadily, with nearly 250 articles published in 2015 on this topic (154 on insect repellents, 42 on insect antifeedants and 52 on insect deterrents) according to the ISI 'Web of Knowledge'. 
A repellent is currently defined as a behavioral response to a stimulus (Miller et al. 2009) and the differences between behavioral responses can be subjective. Historically, the word 'repellent' has indeed been used to characterize many different phenomena. In addition, comparisons of results from different studies worldwide are difficult due to the variability in the methods used to assess repellent, i.e., authors use different apparatuses and/or conditions, variables and parameters.

The word repellent derives from the Latin verb repellere, meaning 'to reject'. Hence, strictly speaking, a substance should only be considered as a repellent when it causes an organism to make oriented movements away from its source (Nordlund 1981). In this review, we use a broader definition of repellent, i.e., a phenomenon that prevents a pest's ability to track, locate and/or recognize its host. Hence, a repellent phenomenon can be a movement away from an odor source, but also an inability to find the host. A mechanism that nullifies the attraction of an insect to an odor source should also be considered as a repellent (Ramirez et al. 2012).

Using this broad definition, we can identify five types of repellent on the basis of the observed insect behavior: (1) true repellent (also called expellent, spatial repellent), which corresponds to an oriented movement of the insect away from an odor source without direct contact, (2) odor masking (also called attraction inhibition), which is either a reduction in the attractiveness of the host or a disruption of the localization of the host by the odor cue, (3) contact irritancy (also called landing inhibition or excito-repellent), an oriented movement of the insect away from a chemical after direct contact, (4) deterrence (also called antifeeding, suppressant, anorexigenic and anti-appetant), which corresponds to a disruption of feeding activity by contact with or ingestion of a chemical and (5) visual masking, which defines a reduction in the attractiveness of the host or a disruption of the localization of the host by a visual cue (Fig. 1).

Here, we review these repellent phenomena by giving each a precise definition and illustrating this with experimental findings. Then, after summarizing the olfaction and gustatory pathways, we discuss the potential action mechanisms of repellents. To illustrate the potential of repellent in insect management to protect humans or plants, we review two examples of well-known strategies, i.e., the use of impregnated bed nets for disease control and the push-pull strategy for crop pest management.

\section{Repellent phenomena}

\section{True repellent: expellent}

A true repellent-sometimes named expellent in medical entomology (Achee et al. 2012) - is a substance that causes oriented movement away from the odor source (Matthews and Matthews 1978; Bernier et al. 2007; Nerio et al. 2010). One example is the aphid alarm pheromoneincluding (E)- $\beta$-farnesene which is the main, if not only, component in most species-which induces the dispersion of the aphids (Montgomery and Nault 1977). Movement away from the odor source can be innate or acquired by experience (White 2007). In pest management, the aim of a true repellent is to create an odor barrier to prevent an arthropod from entering a space occupied by a potential host, as a 'safe zone' to reduce encounters between the insect and the host (Brown and Hebert 1997). In the case of a pathogen vector, the probability of pathogen transmission could be reduced or even eliminated (Achee et al. 2012).

True repellent should be tested: (1) using a bioassay that prevents contact between the insect and the stimulus and (2) in the absence of the host, because it can have a masking effect and/or disturb the tested insect. The repellent can be studied with a tubular olfactometer oriented vertically or horizontally with flowing or still air (Deletre et al. 2013; Deletre et al. 2015; Abtew et al. 2015). A new tubular olfactometer system was recently designed by Steck et al. (2012) for assaying Drosophila melanogaster. Five tubes were aligned horizontally with one insect inside. Using air flow, the insect was exposed to repeated odor pulses. Its position was visually tracked: repellent odors evoke decreased activity followed by downwind movement, whereas attractive odor elicits directed upwind movement. Using this system, Steck et al. (2012) showed that benzaldehyde, a wellknown repellent compound, elicited a true repellent response. Conversely, most other aversive compounds elicited neither attraction nor aversion. The four-arm olfactometer, first designed by Pettersson (1970), can also be used to study attractive or repellent odor. One arm delivers the test odor and the three other arms are used as controls (Pettersson 1970; Vet et al. 1983; Abdullah et al. 2014). The same scheme can be used for testing a repellent (Bruce et al. 2015). It is hard to study a repellent with a $\mathrm{Y}$ olfactometer, because the insect will not go all the way to the choice zone if the compound is a true repellent. To get around this issue, we can either put the insect directly in the choice area or use a T-maze (Stensmyr et al. 2012). For example, Grieco et al. (2005) put Aedes aegypti mosquitoes in the central part of a cylinder divided into three parts. The mosquitoes chose between a treated (repellent odor) and a non-treated chamber. Video recording technology (e.g., Ethovision ${ }^{\circledR}$ software from Noldus) facilitates data collection in behavioral assays for the repellent. This bioassay is now recommended by the World Health Organization (WHO 2013). 


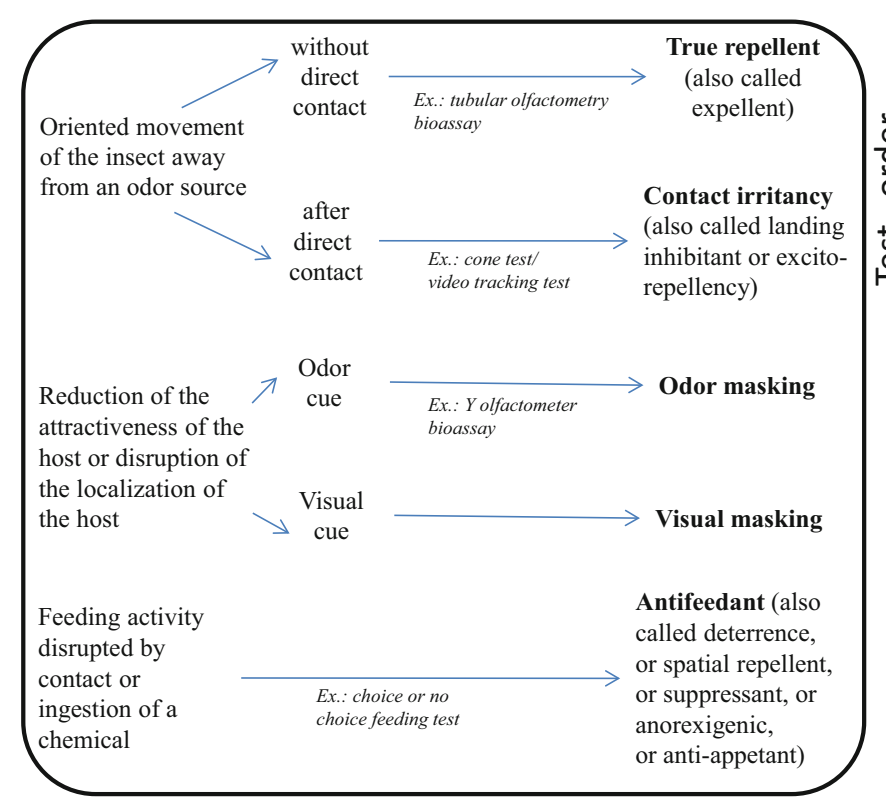

Categories of repellence based on behavior of pest insects

\section{Classification based on observations}

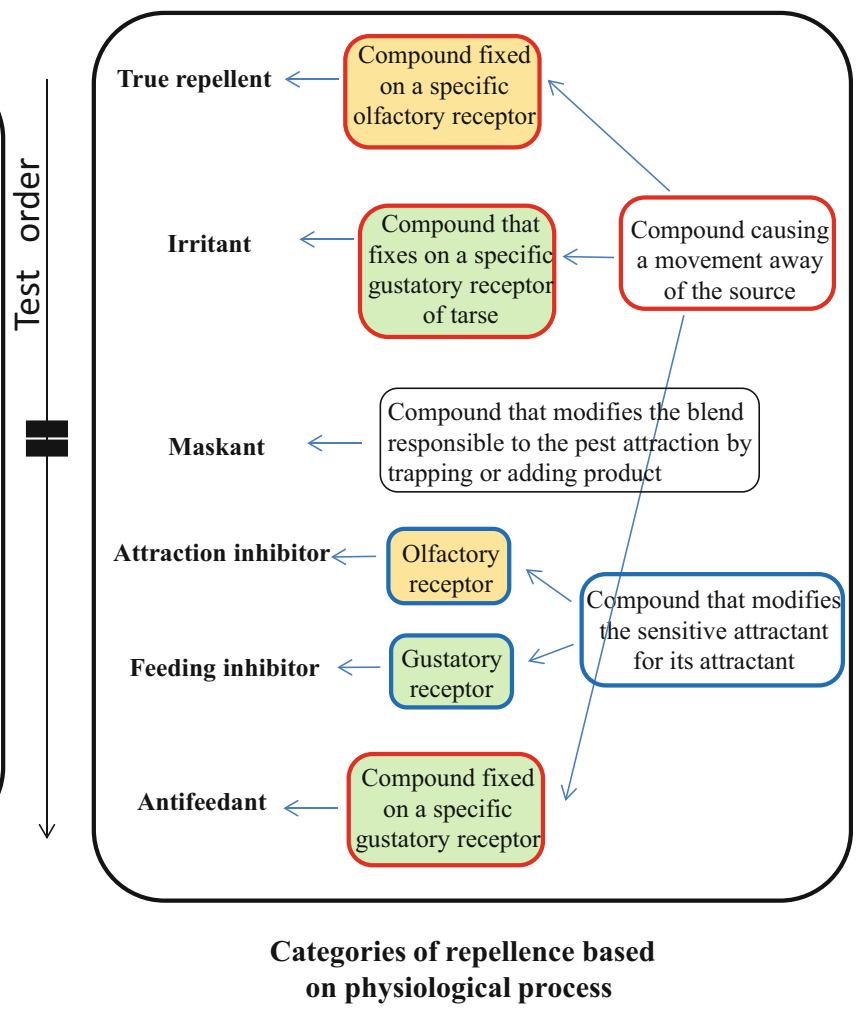

Classification based on mechanisms

Fig. 1 From the repellent definitions based on behavioral responses to definitions based on their neural mechanism. The test order as a function of the behavioral response enables to determine the properties of a candidate repellent product

\section{Odor masking: attraction inhibition}

A masking odor interferes with the host detection/localization or decreases the attractiveness of the host (Nolen et al. 2002; Bernier et al. 2007; WHO 2013). Such compounds are therefore not repellent alone. One example is the N,N-diethyl-3-methylbenzamide (DEET) which inhibits the lactic acid attraction of Aedes aegypti mosquitoes (Dogan et al. 1999). Masking odors can also decrease the host attractiveness by changing the host chemical, thereby impeding an insect's host-seeking activity. For instance, DEET can reduce 3-octenol release, hence changing the chemical host profile and disrupting host-seeking behavior (Syed and Leal 2008). In pest management, the aim of an odor-masking agent is to hide the host from the insect pest.

The masking effect should be evaluated: (1) using a bioassay that prevents contact between the insect and the stimulus and (2) with the host volatile. Y and four-arm olfactometers can be used to assess masking effects (Togni et al. 2010). For the Y-tube, one arm contains the hostanimal or plant-attractant odor and the other contains both the host attractant odor and the tested product. This test is currently recommended by WHO (2013). For the four-arm olfactometer, all the arms contain the host odor but one arm also contains the repellent odor (Irmisch et al. 2014). If the product seems to be a maskant, the best is to test the product alone-i.e., in the absence of the host- to eliminate a potential expellent property.

\section{Irritability (excito-repellent, landing inhibition, contact disengagement)}

An irritant causes movement away from the stimulus after the insect has physically contacted it (Grieco et al. 2005; Miller et al. 2009). In medical entomology, this behavior is also called landing inhibition (WHO 2013) or excito-repellent for the pyrethroids, because they increase mosquito activity after contact (White 2007). In pest management, the aim of an irritant product is to break the physical association between insects and hosts, hence reducing the probability of feeding and the risk of pathogen transmission (Achee et al. 2012).

By definition, the irritant effect must be tested using an experimental arena: (1) allowing contact between the insect and the tested product and (2) in the absence of the host. For crawling insects, Petri dish bioassays are common (Jilani and Saxena 1990). A filter paper is divided into two equal areas, one with the test stimulus and the other with 
solvent only. The insects are released at the center of the Petri dish, and the number of insects found in the two areas and/or the time spent on each area is compared (Nilsson and Bengtsson 2004; Wang et al. 2006; Martin et al. 2013). Because a stimulus could be toxic, the challenge is to work at a sub-lethal concentration (Schrek 1977). For flying insects, such as mosquitoes, a plastic cone where a treated material is placed at the base of the cone is used. After a short acclimation time, the mosquito lands on the treated material and then the time before takeoff is recorded. Another method involves the use of a cylinder divided into two parts: a chamber lined with a treated paper and another chamber lined with a non-treated paper separated by a butterfly valve (Grieco et al. 2005; Deletre et al. 2013). The mosquitoes are placed in the treated chamber, the valve is opened and the number of mosquitoes in the non-treated chamber is recorded $10 \mathrm{~min}$ later to characterize the irritant effect. This should be compared to the effect with a grid avoiding contact with treated paper using the same apparatus to differentiate between compounds having only irritant effect and compounds with irritant and expellent effect.

\section{Antifeeding (suppressant, deterrent, anorexigenic, attraction antagonist, feeding inhibitor)}

An antifeedant product prevents, interrupts or otherwise disrupts feeding behavior (Koul 2008). This change in feeding behavior either occurs after the insect contacts the antifeedant or as postgustatory effects of the antifeedant. Here, we focus on the first cause. Contrary to an irritant, an antifeedant may not cause the insect to move away from the product, but only inhibit its feeding behavior. A suppressant inhibits the initiation of feeding, a deterrent impedes the continuation of this behavior and an anorexigenic causes a loss of appetite (Warthen and Morgan 1990). For example, the tobacco hornworm, Manduca sexta, approached the deterrent Grindella-treated diet but rejected it within $6 \mathrm{~s}$ of initiating biting (Glendinning et al. 1998). In medical entomology, a product interfering with feeding behavior is called a feeding inhibitor (WHO 2013), a substance that interrupts the blood-feeding process is an attraction antagonist (Bernier et al. 2007) and the term deterrent is used in a broad context, i.e., prevention of mosquitoes from bite or even entering a house (White 2007). In pest management, antifeedants reduce or stop feeding behavior (Foster and Harris 1997).

To test the antifeeding effect, the insect must be (1) in contact with the test compound and (2) the host simultaneously. For such studies, it is advisable to use both choice and no-choice assays, because data are complementary and often provide a clearer view of the response. For example, Blaney et al. (1990) showed that compounds recorded as active antifeedants in the choice bioassay were not always as active in the no-choice test. Response variables measured in antifeeding studies include the amount of diet consumed (Abdelgaleil et al. 2002), weight gain of insects, duration of feeding activity (Cameron et al. 2016) and behavioral reflexes (Amrein and Thorne 2005).

\section{Visual masking}

A compound or an object can modify the shape or color of a crop or hide the host, hence ensuring a visual masking effect. In pest management, the aim is to disrupt host plant recognition. The visual stimulant may be used as an attractant stimulant combined with insecticides or glue to trap them. For example, blue and black traps are used to control or survey cattle flies, but it is possible that some colors could be repelling (Gibson and Torr 1999). It seems difficult to change the visual properties of a plant to decrease its attractiveness but, for example, gibberellic acid has been used to keep grapefruit green, which is less attractive than yellow fruit to fruit flies (Foster and Harris 1997). The use of UV-absorbing plastics as greenhouse covers may also reduce the spread of insect-borne virus diseases (Raviv and Antignus 2004). This is because these UV-absorbing plastics modify insect behavior: (1) in a high UV reflectance environment, anthophilous thrips are repelled from the surface of attractive colors, (2) in the whitefly, B. tabaci, adult dispersion was hindered with UV light filtration and (3) in an UV-deficient environment, the flight activity of the aphid, Myzus persicae, was reduced. Moreover, colored shade netting may be effective against insect pests: whiteflies landed on yellow nets but did not penetrate to reach the plant, and thrips were less likely to penetrate through blue and yellow nets (Weintraub 2009). Finally, maize is often used to dissimulate some crops to their pests and can therefore be considered as a visual masking plant (Smith and McSorley 2000). Studies of visual effects should take care to eliminate or otherwise control for effects of olfactory cues.

\section{Potential action mechanisms}

The sources of potential repellent products are diverse (Foster and Harris 1997), but can be classified into three categories: (1) plant sources, (2) insect sources and (3) synthetic compounds. Repellents can originate from plants for several reasons. First, several plants have specialized organs to repel enemies: the nettle Urtica has trichomes, lemon possesses oil vacuoles in the peel, mint has extracellular glands and pine has resin canals (Hossaert-McKey and Bagnères-Urbany 2012). Plants also emit volatile organic compounds to attract pollinators, predators and 
parasitoids or to repel pests, e.g., tobacco plants release herbivore-induced volatiles that are repellent for Heliothis virescens female moths (De Moraes et al. 2001; Kessler and Baldwin 2001; Unsicker et al. 2009). These induced secondary metabolites of plants can be antidigestive and antinutritive proteins (Baldwin et al. 2001). Finally, the essential oils of the major plant families (Myrtaceae, Lauraceae, Lamiaceae, and Asteraceae) may be irritants, repellents, antifeedants, or maskants (Regnault-Roger 1997; Tawatsin et al. 2001; Isman 2006; Moore et al. 2007a; Regnault-Roger et al. 2012; Nerio et al. 2010). Insects are another source of repellent products. Some of them produce defense secretions such as alarm pheromones (Pickett et al. 1992). Another famous example concerns ant cues that affect landing behavior of fruit flies (Van Mele et al. 2009). Synthetic compounds are the third source of repellent products; these include DEET, IR3535, DEPA (N,N-diethyl phenylacetamide), PMD (p-menthane-3,8diol), picaridin and some pyrethroids (Moore and Debboun 2007b). How do these repellent products, synthetic or extracted from plants and animals, act on the insects?

\section{Olfaction pathway}

Insect olfactory organs, the antennae and maxillary/labial palps, are covered with different types of sensilla. A sensillum is a sensory structure housing one to four olfactory receptor neurons (Dethier 1954). Each olfactory receptor neuron expresses a unique combination of olfactory receptors with olfactory co-receptors (Vosshall et al. 2000; Krieger et al. 2003; Vosshall and Hansson 2011) and projects axons into a single olfactory glomerulus in the antennal lobe (Vassar et al. 1994). In the antennal lobe, interneurons are located between glomeruli and projection neurons (PNs) (Jefferis et al. 2001; Marin et al. 2002). Projection neurons link the antennal lobe to higher-order processing centers: mushroom bodies and the lateral horn (Christensen and White 2000). Olfactory signal transduction is detailed in Fig. 2. Insects recognize their hosts by their odors, characterized by: (1) blends of volatile compounds, (2) their ratio and (3) their spatiotemporal diffusion (Sachse and Galizia 2003; Bruce et al. 2005).

The first step in odor recognition is odorant receptor activation (Suh et al. 2014). This could be due to the odor alone or to the binding protein-odorant complex (Buck and Axel 1991; Nakagawa et al. 2005; Leal 2013). Binding proteins contribute to the overall odorant specificity and sensitivity of the insect olfactory system (Vogt and Riddiford 1981; Leal 2013). Olfactory receptors play a significant role in odorant sensitivity, because of the available number, their specificity and affinity (Ha and Smith 2009; Gomez-Martin et al. 2010). Olfactory co-receptors take part in signal transduction and assist in receptor trafficking, targeting and tuning (Larsson et al. 2004; Hansson and Stensmyr 2011; Kaupp 2010). For example, in Anopheles gambiae, De Genarro et al. (2013) showed that Orco mutant mosquitoes were less attracted to honey and did not respond to human scent in the absence of $\mathrm{CO}_{2}$, because the spontaneous activity and odor responses of the Orco mutant olfactory neurons were reduced.

All olfactory receptor neurons expressing the same receptor converge onto one glomerulus (Laissue et al. 1999; Gomez-Martin et al. 2010). However, one olfactory receptor can recognize multiple odors and one odor can be recognized by multiple olfactory receptors. Consequently, a blend of odors activates different combinations of olfactory receptors (De Bruyne et al. 1999; De Bruyne et al. 2001; Hallem and Carlson 2006). Odors can also inhibit odorant receptors (De Bruyne et al. 1999; Hallem and Carlson 2006) and elicit different temporal responses, so temporal coding also enhances the insect ability to recognize odors (Kaupp 2010). Odorant receptors have different activation thresholds and glomeruli have different levels of excitation (Hallem and Carlson 2006). Odor information is therefore coded by the distribution of several activated glomeruli, corresponding to activated olfactory receptor neurons by the odorant molecule (Malnic et al. 1999; Séjourné et al. 2011). Odor information is treated by local interneurons that are the link between olfactory receptor neurons and projection neurons. They modulate, by inhibition or activation, the glomeruli, thus improving the signal from the initial noise that results from odor code conveyed by the projection neurons (Jefferis et al. 2001; Marin et al. 2002; Silbering and Galizia, 2007; Cunningham, 2012). Cortical representations of odor information created in the antennal lobe are not known (Touhara and Vosshall, 2009). Mushroom bodies are probably sites for olfactory learning and memory and experience-dependent modulation of olfactory behavior, whereas the lateral horn appears to be a site for innate, experience-independent modulation of olfactory behavior (de Belle and Heisenberg 1994; Heisenberg 2003; Gomez-Martin et al. 2010). Pheromone or general odor receptors differ with regard to specificity and selectivity, while being narrowly or broadly tuned and linked to specialist or generalist olfactory receptor neurons, so the generating combinatory code in the antennal lobe is different (Christensen and Hildebrand 2002; Hallem and Carlson 2006; Touhara and Vosshall 2009). An odor-like plant volatile can activate different types of olfactory receptors in various neurons converging on different glomeruli, contrary to pheromone receptors which are very specialized (Touhara and Vosshall 2009; Leal 2013). But some olfactory receptor neurons involved in host volatiles can also be highly specialized, depending on their concentration, number and ecological relevance (Hansson and Stensmyr 2011). For example, scarab beetles 

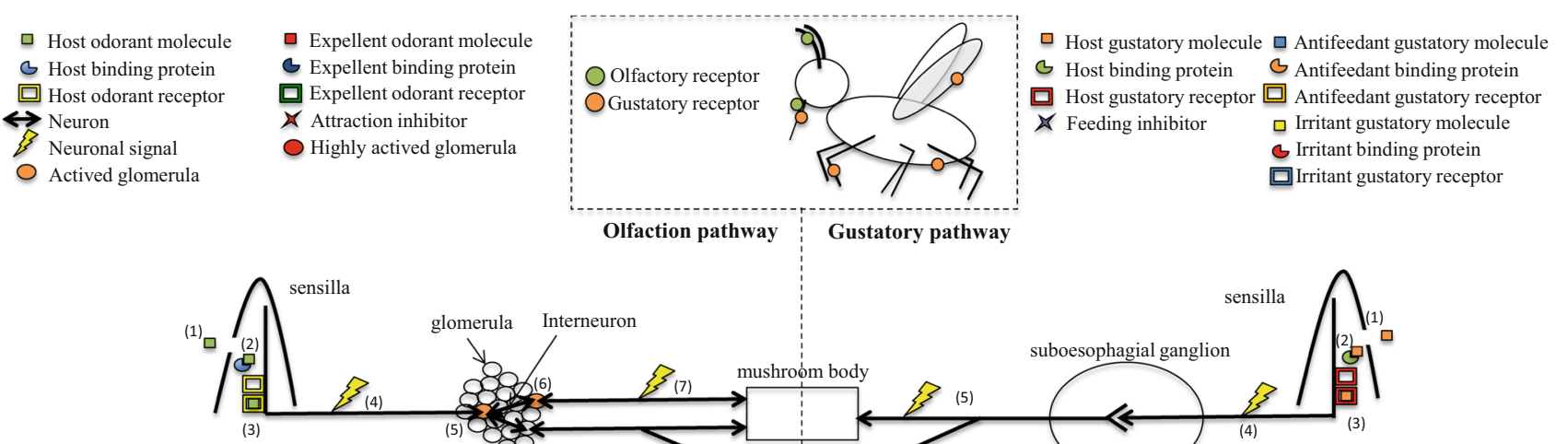

A Host detection by olfaction pathway
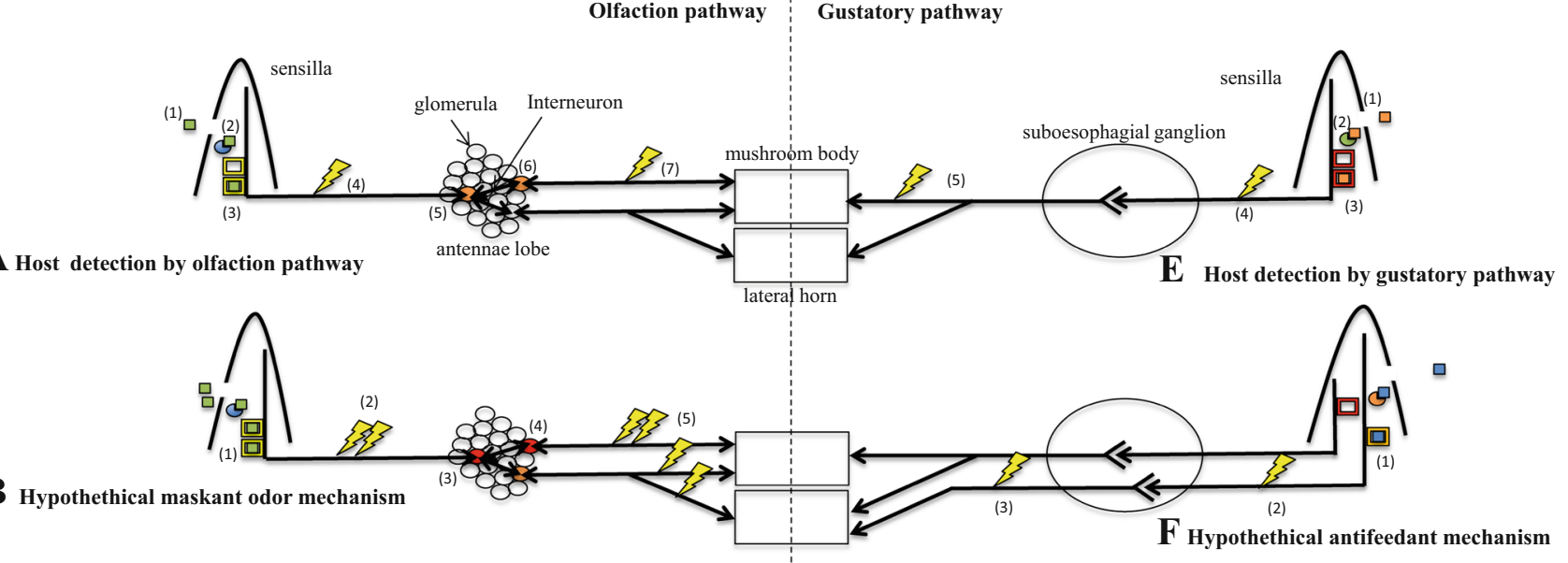

B Hypothethical maskant odor mechanism

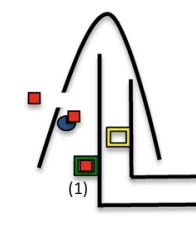

C Hypothethical expellent mechanism

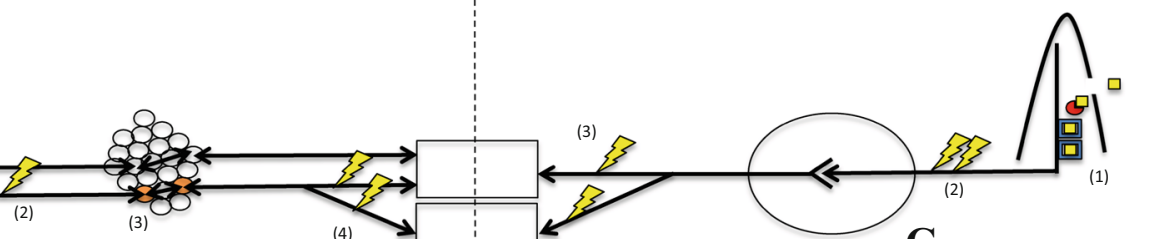

G Hypothethical irritant mechanism

D Hypothetical attraction inhibitor mechanism

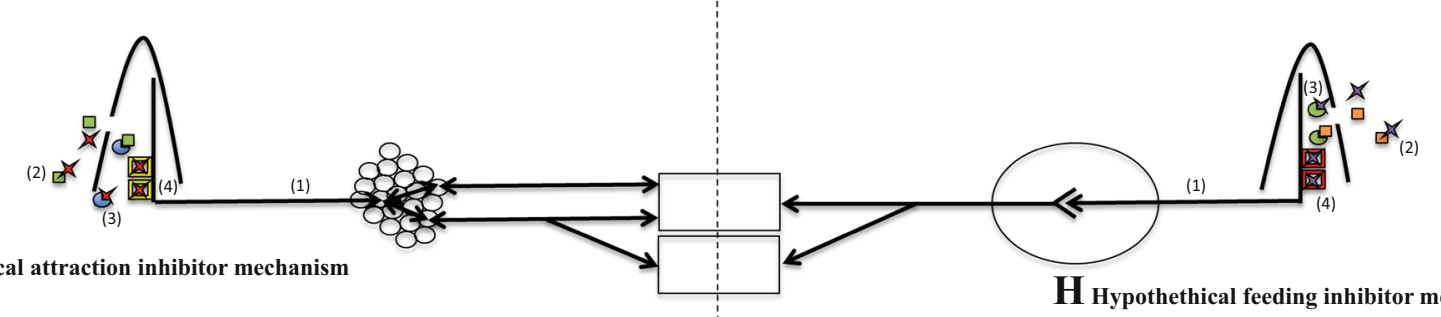

have selective olfactory receptor neurons for specific host volatiles that can elicit either repellent or no behavior. How might a single compound acting on this olfactory system result in a repellent? The molecular targets and signaling pathways involved in sensing insect repellents as well as antifeedants are poorly understood (Kim 2013).

\section{Specific receptors or neurons?}

Here, we hypothesize that the activation of specific olfactory receptor neurons innervating one glomerulus can be responsible for an innate repellent behavior. Accordingly, Knaden et al. (2012) found some glomeruli that responded discriminately to attractive and aversive odors: DA4 and DC3 glomeruli were identified as 'aversive specific', both at the input and output levels. For example, geosmin-a compound produced by fungi and bacteria-is a repellent for Drosophila melanogaster through an innate avoidance pathway (Stensmyr et al. 2012). The molecule activates ab4B neurons which are specific only to geosmin and elicit a response from only two PNs (Stensmyr et al. 2012). Moreover, D. melanogaster exhibited strong avoidance to odors $\left(\mathrm{CO}_{2}\right)$ released by stressed flies, and $\mathrm{CO}_{2}$ activated only a single specific glomerulus in the antennal lobe (Suh et al. 2004). Avoidance is lost when this specific glomerulus is inhibited (Suh et al. 2004). Moreover, DEET is detected by the sacculus (antennal structure) of $\mathrm{D}$. melanogaster innervated by axons of Ir40a-expressing neurons (Kain et al. 2013). When synaptic transmission in these neurons was blocked, DEET repellent was decreased for these flies, suggesting that Ir40a neurons are required for repellent triggering. Note that Ir40a is a highly conserved receptor among insects, which could explain the effectiveness of DEET in a wide variety of species.

As defined above, a true repellent (expellent) is a compound that causes movement away from the odor 
4 Fig. 2 Hypothetical mecanisms of the different kinds of repellents. a Signal transduction through the olfaction pathway. Odorant molecules pass through the sensilla pore tubule ${ }^{1}$, diffuse into the endolymph by means of binding proteins ${ }^{2}$ which carry the molecule to olfactory receptors $^{3}$ (Leal 2013). Binding of the odorant to olfactory receptors leads to the opening of ${ }^{4}$ olfactory receptor-associated ion channels and subsequent depolarization of olfactory receptor neurons ${ }^{4}$ (Kaupp 2010). In the antennal lobe, the activated glomeruli activate interneurons ${ }^{5}$ that modulate the activity of projection neurons ${ }^{6}$ and depolarization in projection neurons conveys information to mushroom bodies and the lateral horn ${ }^{7}$ (Ache and Young 2005). c Hypothetical expellent mechanism. True repellents (expellents) remotely cause movement away from the odor source independently of the context. An expellent would activate specific olfactory receptor ${ }^{1}$ and the depolarization ${ }^{2}$ of the olfactory receptor neuron would activate a specific glomeruli ${ }^{3}$ with labeled lines. Then a projection neuron would convey the information ${ }^{4}$ that codes for a movement away. b Hypothetical maskant odor mechanism. Maskant odor compounds decrease the attractiveness of the host and are not repellent by themselves, but depend on the context. This compound induces different behavior as a function of their concentration and the presence of other molecules. When the concentration is high, a higher number of olfactory receptors are recruited ${ }^{1}$ so the depolarization of olfactory neurons is more important ${ }^{2}$. There is a different threshold activation for glomeruli ${ }^{3}$, which causes different modulation by interneurons ${ }^{4}$. The odor code conveyed by projection neurons ${ }^{5}$ to the higher brain is different from the low concentration code, resulting in different behavior. d Hypothetical attraction inhibitor mechanism. Attraction inhibitors interfere with host detection and localization. These compounds inhibit the olfactory receptor neuron response $^{1}$ by affecting the odorant ${ }^{2}$, binding proteins ${ }^{3}$ or olfactory receptors ${ }^{4}$. There is no signal, so there is no behavior. e Signal transduction through the gustatory pathway. Gustatory compounds pass through the unipore ${ }^{1}$ and diffuse in the endolymph via the host binding protein $^{2}$, which carries them to the gustatory receptor ${ }^{3}$ (Amrein and Thorne 2005; Isono and Morita 2010). Gustatory receptor activation results in opening the ion channel of gustatory receptors and then depolarization of gustatory receptor neurons ${ }^{4}$; their axons project directly without synapsing into the subesophageal ganglion (Schoonhoven and Van Loon 2002). Finally, interneurons are activated ${ }^{5}$ and taste information is sent from the subesophageal ganglion to the mushroom body and the lateral horn (Vosshall and Stocker 2007). f Hypothetical antifeedant mechanism. Antifeedant compounds act on the feeding behavior. Antifeedant compounds activate a specific gustatory receptor ${ }^{1}$ on mouthparts. Depolarization of gustatory receptor neurons ${ }^{2}$ conveys information to the subesophagial ganglion, which gets the information out to the higher brain $^{3}$ for a nonfeeding behavior. Moreover, these compounds activate deterrent cells, inhibit the proboscis extension reflex and thus the feeding activity, but they do not cause a movement away. g Hypothetical irritant mechanism. Irritant compounds cause a movement away from the source after physical contact with it. They would activate a specific gustatory receptor ${ }^{1}$ on tarses. Depolarization of gustatory receptor neurons ${ }^{2}$ conveys the information to the subesophagial ganglion, which gets the information out to the higher brain ${ }^{3}$ for a movement away. The difference between an expellent and an irritant is that the movement away is a distance-mediated behavior through specific olfactory receptors and contact-mediated behavior through specific gustatory rceptors, respectively. $\mathbf{h}$ Hypothetical feeding inhibitor mechanism. Antifeedant compounds act on the feeding behavior. Feeding inhibitors inhibit the gustatory receptor neuron response ${ }^{1}$ by affecting odorants $^{2}$, binding proteins ${ }^{3}$ or gustatory receptors ${ }^{4}$

source independently of the context. It could therefore be a compound that has a specific olfactory receptor and glomeruli with labeled lines that code for a movement away (Galizia and Rossler 2010) (Fig. 2).

\section{A matter of concentration and/or ratio?}

Here, we hypothesize that a compound could provoke different behaviors as a function of its concentration and the presence of other molecules. Depending on the concentration and molecule ratio, activated olfactory receptors, and thus activated glomeruli, result in a different odor code by a different type of interneuron modulation (Knaden et al. 2012). This different odor codes conveyed by the PNs to the higher brain result in different behaviors. Most stimuli that are attractant at low concentration can become repellent at high concentration (Foster and Harris 1997). At high concentration, most fragrant molecules activate multiple receptors, whereas at low concentration fewer receptors are activated (Malnic et al. 1999; Hallem and Carlson 2006). The recruitment of additional glomeruli has been proposed as a mechanism mediating this switch in behavioral response. Hence, in D. melanogaster two glomeruli, DM1 and VA2, were identified as mediators of attraction to vinegar at low concentration. At high concentration, vinegar became aversive and active on another glomerulus, DM5, which mediates the decreased attraction (Semmelhack and Wang 2009). Actually, odorant receptors have different activation thresholds and glomeruli also have different levels of excitation (Hallem and Carlson 2006). Individual odors activate distinct subsets of olfactory receptors, resulting in the construction of a glomerular activation pattern-odor map-but different concentrations result in different patterns (Knaden et al. 2012). The different glomerular activation pattern initiates different projection neuron responses via local interneuron activity (Sachse and Galizia 2003; Knaden et al. 2012).The response increased in amplitude and duration with increasing odor concentration up to a saturated maximum for input and output neurons. Interestingly, the behavioral response did not depend only on the concentration of a compound, but also on its ratio with other compounds. Several volatiles which are attractant as a blend can be each individually repellent. For instance, the black bean aphid, Aphis fabae, is attracted by the volatile blend produced by Vicia faba (host cue), but when the volatiles were presented alone they were not bioactive (Webster et al. 2010). A similar scenario is exhibited in the context of masking odors, e.g., in the case of herbivore-induced plant volatiles, an increase in some volatiles decreases the host attractiveness (Turlings et al. 2002). Thus, the context results in a different odor code by a different type of interneuron modulation (Fig. 2). Insects can differentiate between host and non-host plants, healthy vs stressed plants and unripe vs ripe fruits, despite cues with overlapping patterns of odors, through the processing of odor information by interneurons in antennal lobes (Cunningham 2012). So, a repellent might not be due to only one 
compound and its concentration, i.e., the context and presence of other compounds are also important.

\section{Information blocker?}

Repellent compounds could affect the olfactory receptor function by modifying or blocking the response of olfactory receptor neurons sensitive to attractants (Davis 1985). For example, inhibitors of the mosquito $\mathrm{CO}_{2}$ receptor can mask attraction to human odors (Ray 2015). Bohbot et al. (2011) showed that IR3535 and DEET inhibited the response of a complex olfactory receptor $(\mathrm{AaOr} 8+\mathrm{AaOr} 7)$ of the mosquito Aedes aegypti to octenol, an attractant. In this mosquito, DEET decreases the sensitivity of sensitive olfactory receptor neurons to lactic acid, a compound in human sweat (Davis and Sokolove, 1976). Tsitoura et al. (2015) also showed that specific mosquito repellent such as ethyl cinnamate inhibits odorant receptor function through a functional blocking of olfactory co-receptors and Ditzen et al. (2008) showed that DEET blocked the response of olfactory neurons by decreasing the current mediated by the olfactory receptor due to a change in ion permeability.

We have defined a masking odor as a compound that interferes with host detection and localization and can modify the host profile. It could therefore correspond to a compound that inhibits the olfactory receptor neuron response by affecting olfactory receptors, binding proteins or by trapping the attractant (Fig. 2). Acting on the attractant is actually another way to block the information. For example, DEET decreases octenol release, lowering its stimulation on specific olfactory receptors, which in turn changes the chemical host profile and reduces the host attractiveness. DEET might therefore be viewed as an attractant trap (Syed and Leal 2008). But this mode of action is controversial.

\section{Gustatory pathway}

Taste organs are distributed over multiple body parts: mouthparts (maxillary palps, oral cavity and pharynx), legs and wings (De Boer 2006; Vosshall and Stocker 2007). Sensilla on these organs enable the insect to sample potential food sources without consuming them (Sturcow 1959; Montell 2009). External gustatory sensilla are uniporous, contrary to olfactory sensilla, which are multiporous (Altner and Prillinger 1980; Fig. 2). Gustatory sensilla have two kinds of gustatory receptor neuron cells responding to attractive tastants or aversive tastants, or four kinds of gustatory receptor neuron cells responding to sugar ( $\mathrm{S}$ cells), tap water (W cells), low salt concentrations (L1 cells), high salt concentrations and bitterness (L2 cells) (Rodrigues and Siddiqi 1981). They include one chemosensory neuron and several types of accessory cells
(Amrein and Thorne 2005; Montell 2009). Odorant-binding proteins are also expressed in the lymph of gustatory sensilla and have the same role as odorant-binding proteins in the olfactory system (Amrein and Thorne 2005). Like olfactory receptors, gustatory receptors form heterodimers with other receptors as a common co-receptor such as Gr64f (Isono and Morita 2010). Transduction of chemical information occurs in the mouthparts via gustatory receptor neurons when molecules make contact with taste receptor cells composed of trans-membrane proteins (Isono and Morita 2010). In the proboscis, taste receptor neuron axons project directly without synapsing into the subesophageal ganglion, which provides motor output to those mouthparts (Schoonhoven and Van Loon 2002). The subesophageal ganglion contains no morphologically apparent structural subdivisions, such as glomeruli in the antenna lobe (Vosshall and Stocker 2007). But projections of gustatory receptor neurons into the subesophageal ganglions terminate in spatially segregated domains (Dunipace et al. 2001; Thorne et al. 2004; Wang et al. 2004; Isono and Morita 2010). Gustatory afferents from the pharynx, labellum and legs traveling through different nerves terminate in distinct areas of the subesophageal ganglion, and some of these spatially distinct afferents express the same receptors, suggesting that a given tastant may trigger different behaviors depending on the stimulation site (Vosshall and Stocker 2007). Interneurons also link the subesophageal ganglion to the mushroom body (Melcher and Pankratz 2005; Vosshall and Stocker 2007). Taste information is sent to higher brain centers, while simple reflexes, such as proboscis extension or food ingestion, may rely on local circuitry with fairly limited processing.

Like the olfactory system, the gustatory system codes quantitatively, qualitatively and by the compound's ratio as well as the compound's presence in space and time (Schoonhoven and Van Loon 2002; Koul 2008). For example, glucose-sensitive cells in Manduca sexta responded differently to sucrose or glucose. The differences could be attributed to the topographical binding-site characteristic of gustatory receptors (Lam and Frazier 1991). Many gustatory receptors are co-expressed in the same gustatory receptor neurons (Montell 2009). In contrast to one receptor $=$ one neuron in the olfactory system, different gustatory receptor subsets are expressed in one taste neuron. Multiple receptor expression may be able to expand the ligand spectrum, but decrease the discrimination performance (Isono and Morita 2010). Finally, there are three types of sensory coding: (1) each neuron conveys a specific message to the central nervous system, (2) the global message is contained in a neural activity pattern (input) transmitted by several receptors and (3) the stimulus quality affects nerve impulse patterns (output) and the adaptation rate, which may contain additional information (Schoonhoven et al. 1992). 
How could a compound acting on this gustatory system result in a repellent behavior? A first response is that behavioral rejection is not due to the ingested product, but to external receptors because there is no link between feeding deterrence and internal toxicity (Koul 2008). Since the gustatory system is quite similar to the olfactory system, the same hypothesis regarding the mode of physiological action could be put forward to explain the repellent effects, such as antifeeding and irritancy.

\section{A matter of concentration, ratio or time?}

Drosophila spp. are attracted by low salt concentration. Conversely, they are averted by high salt concentration. Two categories of neurons respond to $\mathrm{NaCl}$ : $\mathrm{Gr} 5 \mathrm{a}$ for low concentrations and Gr66a for high concentrations (Thorne et al. 2004; Wang et al. 2004; Marella et al. 2006). All compounds activating Gr5a neurons are attractive to flies and all those activating Gr66a neurons are aversive. But the Gr66a neuron alone did not explain the salt aversion, because its ablation did not significantly affect salt avoidance (Yarmolinsky et al. 2009).

Host plant selection depends on the balance of phagostimulant (e.g., sugars) and deterrent (e.g., plant secondary compounds) inputs, so the selection depends on the compound's concentration (Schoonhoven 1987; Chapman 2003). Actually, plant secondary compounds are usually, deterrent but they also stimulate phagostimulatory cells. For example, in the Colorado potato beetle, Leptinotarsa decemlineata, epipharyngeal taste sensillum is innervated by five neurons (one responds to water, one to sucrose and three to two antifeedants (drimane, sinigrin), but sucrosesensitive cells are also strongly inhibited by drimane (Messchendorp et al. 1998). One hypothesis is that electrical signals from receptor cells sensitive to antifeedants are subtracted algebraically to electrical signals from receptor cells sensitive to feeding stimulants in the central nervous system (Schoonhoven and Van Loon 1988).

The concentration, and particularly the exposure time can play a key role in stimulation or inhibition of the neuronal response. For example, taste cells in the butterfly Pieris brassicae responding to phagostimulants showed a gradual decrease in sensitivity to drimane (antifeedant) at high dosage for periods up to $30 \mathrm{~min}$ (Schoonhoven and Van Loon 2002).

\section{Specific receptors or neurons?}

All phytophagous insects have deterrent receptors which, upon stimulation, reduce or fully stop feeding activity (Schoonhoven and Van Loon 2002). Like the olfactory system, the gustatory system could be modulated by learning and memory (Vosshall and Stocker 2007).
Moreover, evolution has led to the selection of specific receptors to deterrents. Deterrent cells generally show greater latency in their response than phagostimulatory cells (Schoonhoven and Van Loon 2002). For example, in the labellum, bitter aversive compounds are primarily detected via L2 cells and they also inhibit S and W cells (Montell 2009). Moreover, at the labellum, pharynx and subesophageal ganglion level, DEET can activate bittersensing deterrent neurons in D. melanogaster, which could explain its efficiency in repelling insects (Lee et al. 2010; Sanford et al. 2013; Kain et al. 2013).

We defined an antifeedant as a peripheral-mediated behavior-modifying substance resulting in feeding deterrence (Isman 1994). An antifeedant could be a compound that has a specific gustatory receptor that codes for a nonfeeding behavior (Fig. 2). Actually, the compounds that activate deterrent cells inhibit the proboscis extension reflex and thus the feeding activity, without causing the insect's movement away from the stimulus.

Gamma aminobutyric acid (GABA) stimulates feeding and triggers a taste cell response among herbivorous insects, and the antagonists of GABA causes feeding deterrence along with hyperexcitation of the central nervous system and has an excitoirritant effect (Rattan 2010). We have defined an irritant as a compound that causes a movement away from the source after physical contact with it. An irritant could therefore be a compound that has a specific gustatory receptor coding for movement away (Fig. 2). The difference between an expellent and an irritant is that the movement away is a distance-mediated behavior through specific olfactory receptors and a contactmediated behavior through specific gustatory receptors, respectively. De Gennarro et al. (2013) showed that even in the presence of DEET, Orco mutant female mosquitoes were still attracted to human hosts, but were repelled upon contact. This indicates that olfactory- and contact-mediated effects of DEET are mechanistically distinct, thus supporting our hypothesis that irritancy is coded by gustatory receptors on the tarsus.

\section{Information blocker?}

We hypothesize that a compound can block the stimulant taste receptor. According to Koul (2008), the sensory code may be altered due to the stimulation of specialized receptors and also to modulation of the activity of receptors tuned to other compounds. Although antifeedant compounds do not stimulate any neurons within a sensillum, they may decrease the responsiveness of a cell responding to a nutrient (Schoonhoven and Van Loon 2002). For example, deterrents may inhibit $\mathrm{S}$ cells (Schoonhoven and Van Loon 2002). In mouthparts of lepidopteran larvae, terpenes block the stimulatory effects of glucose on 
chemosensory cells, thus inducing an antifeedant effect (Rattan 2010). Azadirachtin, the main active compound of neem oil, stimulates deterrent receptors in various insects (Schoonhoven 1988), but also appears to inhibit sugar or inositol receptors in other species (Schoonhoven 1988). Sinigrin inhibits inositol cells in the moth Heliothis virescens (Bernays and Chapman 2000).

We have defined an antifeedant as a compound acting on feeding behavior. An antifeedant that we have called a feeding inhibitor could therefore be a compound that inhibits the gustatory receptor neuron response by affecting gustatory receptors (Fig. 2).

As clearly outlined by Dickens and Bohbot (2013), the mode of action of mosquito repellents has been widely studied, particularly for DEET, the potential molecular targets and their numerous neurophysiological pathways. But it is still not clear which target initiates the repellent phenomenon. We should also stress the plasticity of the sensory system and the faculty of insects to adapt to rapid environmental changes. The avoidance behavioral response can actually be modulated by experience and memorized in the short and long term (Séjourné et al. 2011). In the mushroom body, MB-V2 neurons are specifically required to retrieve aversive olfactory memory. Aversive odor represses their activity and the reduced response could lead to enhanced avoidance to the aversive odor, resulting in lower inhibition of olfactory signaling mediated by the lateral horn. Other neurons provide the output for appetitive memory, but the process could be the same.

Receptor types other than olfactory and gustatory receptors could be involved in repellent phenomena. Transient receptor potential (TRP) channels are non-selective ion channels and participate in the detection of pain, hot temperature, gravity sensation, sound sensation, visual transduction and chemosensation (Kim 2013). For example, TRPA1 is required for avoiding the volatile insect repellent citronellal (Kim 2013). In Drosophila, citronellal interacts with TRPA1, modifying the activity of the $\mathrm{Ca} 2^{+}$activated potassium channel, but TRPA1 is directly activated by citronellal in An. gambiae (Kwon et al. 2010).

\section{Two examples of repellent use}

\section{Advantages/disadvantages of repellent use}

One advantage of using repellents is the durability of their efficacy over time (Achee et al. 2012). The selection pressure from contact-mediated toxicity, like chemical insecticides, is generally high and rapidly selects for resistance (REX Consortium 2013), while the selection pressure from a repellent that modifies behavior may be lower. This is because repellents concomitantly increase the predation risk and the energy expenditure, but also allows the insects to find an alternative host (Achee et al. 2012). The lower risk of resistance could be also explained by higher fitness costs associated with resistance to repellents. For these reasons and because repellents are currently underutilized in public health and domestic hygiene, no case of resistance to these products has been documented. On the contrary, data suggest that changes occur in the efficiency of repellents on insecticide-resistant populations. For instance, Anopheles gambiae-, $k d r$ - and acel-resistant populations were less irritated by pyrethroids, but more irritated by repellents than the susceptible reference strain (Chandre et al. 2000; Deletre et al. 2016). Populations of the German cockroach have rapidly evolved an adaptive behavioral aversion to glucose, the phagostimulatory component of baits (Wada-Katsumata et al. 2013). In both wild-type and glucose-averse cockroaches, D-fructose and D-glucose stimulated sugar-gustatory receptor neurons, whereas the deterrent caffeine stimulated bitter-gustatory receptor neurons (Wada-Katsumata et al. 2013). In contrast, in glucose-averse cockroaches, D-glucose also stimulated bitter-gustatory receptor neurons and suppressed the responses of sugar-gustatory receptor neurons.

One disadvantage of using repellents is that insects can lose their sensitivity to them or they can change their mode of feeding after repeated and prolonged exposure to these products, especially to antifeedants (Jermy 1990; Foster and Harris 1997). For example, when rice plants were treated with neem extracts, Nephotetettix virescens fed on xylem instead on phloem (Saxena and Khan 1985). Several possible mechanisms could explain the behavioral changes, including sensory adaptation, motor fatigue and habituation (Akhtar et al. 2003). Habituation is a learning or temporal desensitization phenomenon, whereas sensory adaptation can be a persistent synaptic change in specific neural pathway (Bernays and Chapman 2000, Koul 2008). Glendinning et al. (2001) showed that the adapted aversive response (exposure-induced adaptation) to caffeine of the moth Manduca sexta is directly mediated by desensitized taste cells.

\section{The push-pull strategy in crop protection}

The push-pull strategy developed by Pike et al. (1987) is a concept that uses attractive and repellent stimuli simultaneously to modify the abundance and distribution of insect pests or beneficial insects (Cook et al. 2007). This method repels the insects away from the resource (by making it hard to locate, unattractive or unsuitable) while simultaneously attracting the insects to another area (Ratnadass et al. 2012). The source (push) depends on the management tactics on visual and/or chemical cues both at short (e.g., through antifeedants, oviposition deterrents, deterring 
pheromones) and long range (through synthetic repellents, non-host volatiles, host volatiles and anti-aggregation, sex or alarm pheromones). The stimulus is generally a plantproduced compound(s), but it can also be a synthetic blend (Cook et al. 2007).

The most famous example of a push-pull strategy is the control of stem borers in maize and sorghum (Khan and Pickett 2004). The push stimulus involves intercropping with a repellent non-host plant such as Desmodium uncinatum, Desmodium intortum or Melinis minutiflora, while the pull stimulus is an attractant trap plant such as Sorghum vulgare sudanense or Pennisetum purpureum (Khan et al. 1997a). Intercropping is based on the odor masking offered by plants with the aim of decreasing the attractiveness of the host crop or hiding this crop to the insect pests via another crop (Cook et al. 2007). For instance, the repellent molasses volatile (E)- $\beta$-ocimene and (E)-4,8-dimethyl$1,3,7$-nonatriene produced by plants damaged by phytophagous insects (Kimani et al. 2000) reduces stem borer infestation and increases parasitism of these borers by the wasp Cotesia sesamiae (Khan et al. 1997b). The intercropping principle and efficiency have been questioned by Finch and Collier (2012). At a few meters from the source, specialist insects respond only to volatile chemicals released by their host plants, even when emitted in small quantities. Tosh and Brogan (2014) suggested that generalist insects such as Bemisia tabaci with a super-abundance of volatiles by intercropping could have a confusion effect. Another example is the control of $L$. decemlineata in potato (Solanum tuberosum) crops (Martel et al. 2005a). The push stimulus involves the use of neem-based antifeedants on the crop (Martel et al. 2005a), while the pull stimulus is ensured by combining attractants (Z)-3-hexenyl acetate, $(\mathrm{R}, \mathrm{S})$-linalool and methyl salicylate on the potato crop, with insecticide applications (Martel et al. 2005b). To improve this system, the beetle aggregation pheromone (S3,7-dimethyl-2-oxo-6-octene-1,3- diol) could be used to concentrate the beetle in the trap crop (Dickens et al. 2002; Dickens 2006).

The push-pull strategy is used in horticulture (Miller and Cowles 1990), forestry (Borden 1997) and for control of veterinary and medical pests (Nalyana et al. 2000). This strategy maximizes the control efficacy, sustainability and yield and minimizes negative environmental impacts (Miller and Cowles 1990; Cook et al. 2007). The combined effect between the pull and push stimuli increases the efficiency of some stimuli, like antifeedants (Jermy 1990). Another advantage of this strategy is that resistance management is facilitated (Foster et al. 2005). Unfortunately, this strategy is often not as effective as the use of a broadspectrum chemical insecticide at reducing pest numbers (Cook et al. 2007). This lower efficacy in pest control is therefore not always economically profitable, especially for crops with low economic incomes. Indeed, this strategy is operationally complex, requiring monitoring and decision systems and thus induces higher operational costs than conventional systems. The lack of general knowledge about insect/plant interactions is also a factor limiting its adoption by small farmers (Ratnadass et al. 2012).

\section{The use of pyrethroids in human health protection}

Pyrethroids were originally derived from natural pyrethrin extracted from Chrysanthemum cinerariaefolium (Elliott et al. 1978). Since then, many other pyrethroids have been synthesized, such as permethrin, bifenthrin, deltamethrin, lambda-cyhalothrin and alpha-cypermethrin. These insecticides are very toxic against most insects due to a modification of the gating kinetics of the voltage-dependent sodium channel (Narahashi 1971). Moreover, they are odorless, resistant to degradation by UV, heat and hydrolysis, and displayed a low toxicity for mammals. All these properties make pyrethroids a powerful and suitable means of pest control in a wide variety of situations.

For instance, bed nets, clothes (e.g., battle dress) and hammocks can be treated by pyrethroids, thus avoiding mosquito bites (Pennetier et al. 2010; Hougard et al. 2007; McCain and Leach 2007). Treated bed nets are recommended by WHO (WHO 2002) against malaria vectors, especially endophagic species responsible for indoor transmission such as Anopheles gambiae and Anopheles funestus. Martin et al. $(2013,2014)$ recently documented the effect of pyrethroid-treated nettings in agriculture to protect cabbage and tomato crops against aphids and whiteflies. These insecticides are indeed irritating (excitorepellent) for the several insects, which therefore avoid landing on the treated surfaces. If insects alight many times on treated areas, they are either knocked down or killed. The knockdown effect involves rapid incapacitation, sometimes with metabolic recovery (White 2007).

In field experiments, the number of mosquitoes entering huts with treated nets was usually lower compared to huts with untreated nets (Adeogun et al. 2012), indicating an expellent or masking effect. The observed withdrawal of female mosquitoes could be explained by the loss of response to host cues rather than repellent (Siegert et al. 2009). Apart from transfluthrin and metofluthrin, most pyrethroids lack the volatility to function as expellents at concentration necessary to be active against mosquitoes under ambient conditions (Achee et al. 2009; Deletre et al. 2013). However, these compounds can still be heated or aerosolized in a room to obtain a sufficient gaseous or suspended concentration to result in expellency (Chadwick and Lord 1977).

Unfortunately, vector management by pyrethroids is jeopardized by the selection of resistance mechanisms. In An. gambiae, pyrethroid resistance can be due to a 
mutation in the sodium channel sequence (Hemingway et al. 2004), which decreases the irritant effects of these molecules (Chandre et al. 2000). Through this mutation or other resistance mechanisms, An. gambiae resistance to pyrethroids has been reported in 27 countries in sub-Saharan Africa, thus underscoring the urgent need to find alternatives to these insecticides (Zaim et al. 2000; WHO 2011; Ranson et al. 2011; Temu et al. 2013). The prioritization of toxic actions over spatial repellent and contact irritant actions should be balanced with the higher risk of rapid selection for resistance to the active compounds (Achee et al. 2009). Moreover, pyrethroids are commonly used to protect crop fields adjacent to An. gambiae habitats, thus contributing to the selection of resistant mosquitoes (Yadouleton et al. 2011).

\section{Conclusion and perspectives}

(1) In this paper, we define insect repellent as a phenomenon that prevents a pest's ability to track, locate and/or recognize its host. We also subdivide repellent into five phenomena: true repellent, odor masking, irritability, antifeeding and visual masking.

(2) The greatest problem with repellent research is the use of bioassays that do not adequately discriminate between these five types of repellents. Consideration of the stimulus that produces these reactions may facilitate this discrimination. For example, Junker et al. (2015) summarized the mode of action and DEET and performed different kinds of bioassays to discriminate the different modes of action. Understanding the mode of action of insect repellents and the ways by which they modulate receptor activity will allow us to design potent formulations aimed at interfering with insect sensory signaling and, ultimately, disrupt their cognitive processes (Dickens and Bohbot 2013).

(3) Insect repellents exert their effects through interactions with olfactory (antennae and maxillary palps) and gustatory (maxillary palps, mouthparts, tarsi and wind) receptors. With greater knowledge on neural mechanisms, the repellent definitions could be based on their modes of action rather than behavioral responses, as highlighted in Fig. 1.

(4) Many potential repellents are available, but their use is still limited. A better understanding of the chemical ecology of pests would be helpful for identifying candidate semiochemicals that could then be used in attractant and repellent formulations (Dickens and Bohbot 2013). The development of repellents might however remain impeded by the economic costs that must be paid to identify those molecules and to perform analyses to ensure that they can safely be used in health and agriculture (Kain et al. 2013). Nevertheless, the discovery and design of new repellents could be achieved more rapidly and at lower costs by molecular-based chemical prospecting (Leal 2007) and by computer-aided molecular modeling (Gupta and Bhattacharjee 2007; Tauxe et al. 2013) confirmed by behavioral assays. In this vein, Kain et al. (2013) developed a high-throughput chemical informatics screen using a structure-activity approach to discover new repellents. Using this technique, they identified a new repellent that activated the same chemosensory pathways as DEET. The need to preserve our environment and to provide efficient and sustainable tools for IPM could strongly foster future prospects on repellent. Chemosensorybased insect control like repellent/antifeedant, trap and the mating disruption strategies might become the most used insect pest management strategies in the near future.

Acknowledgments The work was supported by CIRAD, IRD and MUTAVIE, Paris, France.

\section{References}

Abdelgaleil SAM, El-Aswad AF, Nakatani M (2002) Molluscidal and anti-feedant activities of diterpenes from Euphorbia paralias L. Pest Manag Sci 58:479-482

Abdullah ZS, Ficken KJ, Greenfield BP, Butt TM (2014) Innate responses to putative ancestral hosts: is the attraction of Western flower thrips to pine pollen a result of relict olfactory receptors? J Chem Ecol 40:534-540

Abtew A, Subramanian S, Cheseto X, Kreiter S, Tropea Garzia G, Martin T (2015) Repellency of plant extracts against the legume flower thrips Megalurothrips sjostedti (Thysanoptera: Thripidae). Insects 6:608-625

Ache BW, Young JM (2005) Olfaction: diverse species, conserved principles. Neuron 48(3):417-430

Achee N, Sardelis M, Dusfour I, Chauchan K, Grieco J (2009) Characterization of spatial repellent, contact irritant, and toxicant chemical actions of standard vector control compounds. J Am Mosquito Contr 25:156-167

Achee N, Bangs M, Farlow R, Killeen G, Lindsay S, Logan J, Moore S, Rowland M, Sweeney K, Torr S, Zwiebel L, Grieco J (2012) Spatial repellents: from discovery and development to evidencebased validation. Malaria J 11:164-182

Adeogun AO, Olojede JB, Oduola AO, Awolola TS (2012) Villagescale evaluation of PermaNet 3.0: anenhanced efficacy combination long-lasting insecticidal net against resistant populations of Anopheles gambiae s.s. MCCE 1:1-9

Akhtar Y, Hankin CH, Isman MB (2003) Decreased response to feeding deterrents following prolonged exposure in the larvae of a generalist herbivore, Trichoplusia ni (Lepidoptera: Noctuidae). J Insect Behav 16:811-831

Altner H, Prillinger L (1980) Ultrastructure of invertebrate chemo-, thermo-, and hygroreceptors and its functional significance. Int Rev Cytol 67:69-139 
Amrein H, Thorne N (2005) Gustatory perception and behavior in Drosophila melanogaster. Curr Biol 15:673-684

Baldwin IT, Halitschke R, Kessler A, Schittko U (2001) Merging molecular and ecological approaches in plant-insect interactions. Curr Opin Plant Biol 4:351-358

Bernays EA, Chapman RF (2000) A neurophysiological study of sensitivity to a feeding deterrent in two sister species of Heliothis with different diet breadths. J Insect Physiol 46:905-912

Bernier UR, Kline DL, Posey KH (2007) Human emanations and related natural compound that inhibit mosquito host-finding abilities. In: Debboun M, Frances SP, Strickman D. Insect repellents: principles, methods and uses. New York, USA, CRC Press, Taylor and Francis Group, pp 77-100

Blaney WM, Simmonds MSJ, Ley SV, Anderson JC, Toogood PL (1990) Antifeedant effects of azadirachtin and structurally related compounds on lepidopterous larvae. Entomol Exp appl 743 55(2):149-160

Bohbot JD, Fu L, Le TC, Chauchan KR, Cantrell CL, Dickens JC (2011) Multiple activities of insect repellents on odorant receptors in mosquitoes. Med Vet Entomol 25:436-444

Borden JH (1997) Disruption of semiochemical-mediated aggregation in bark beetles. In: Cardé ED, Minds AK. Insect pheromone research: new directions. Chapman and Hall, New York, pp 421-438

Brown M, Hebert AA (1997) Insect repellents: an overview. J Am Acad Dermatol 36:243-249

Bruce TJA, Wadhams LJ, Woodcock CM (2005) Insect host location: a volatile situation. Trends Plant Sci 10:269-274

Bruce TJA, Aradottir GI, Smart LE, Martin JL, Caulfield JC, Doherty A, Sparks CA, Woodcock CM, Birkett MA, Napier JA, Jones HD (2015) The first crop plant genetically engineered to release an insect pheromone for defence. Scientific reports 5

Buck L, Axel R (1991) A novel multigene family may encode odorant receptors: a molecular basis for odor recognition. Cell 651:175-187

Cameron R, Hopper L, Alvarez JM (2016) Use of fluorescence to determine reduction in Bemisia tabaci (Hemiptera: Aleyrodidae) nymph feeding when exposed to cyantraniliprole and imidacloprid through systemic applications. Crop Prot 84:21-26

Chadwick PR, Lord CJ (1977) Tests of pyrethroid vaporising mats against Aedes aegypti (L.) (Diptera: Culicidae). Bull Entomol Res 67:667-674

Chandre F, Darriet F, Duchon S, Finot L, Manguin S, Carnevale P, Guillet P (2000) Modifications of pyrethroid effects associated with kdr mutation in Anopheles gambiae. Med Vet Entomol 14:81-88

Chapman RF (2003) Contact chemoreception in feeding by phytophagous insects. Ann Rev Entomol 48:455-484

Christensen TA, Hildebrand JG (2002) Pheromonal and host-odor processing in the insect antennal lobe: how different? Curr Opin Neurobiol 12:393-399

Christensen TA, White J (2000) Representation of olfactory information in the brain. In: Bryant BP, Silver WL. The neurobiology of taste and smell. Wiley-Liss, New York, pp 201-232

Cook SM, Khan ZR, Pickett JA (2007) The use of push-pull strategies in integrated pest management. Ann Rev Entomol 52:375-400

Cunningham JP (2012) Can mechanism help explain insect host choice? J Evol Biol 25:244-251

Davis EE (1985) Insect repellents: Concepts of their mode of action relative to potential sensory mechanisms in mosquitoes (Diptera: Culicidae). J Med Entomol 22:237-243

Davis EE, Sokolove PG (1976) Lactic acid-sensitive receptors on the antennae of the mosquito, Aedes aegypti. J Comp Physiol 105:43-54

de Belle JS, Heisenberg M (1994) Associative odor learning in Drosophila abolished by chemical ablation of mushroom bodies. Science 263(5147):692-695
De Boer G (2006) The role of the antennae and maxillary palps in mediating food preference by larvae of the tobacco hornworm, Manduca sexta. Entomol Exp Appl 119:29-38

De Bruyne M, Clyne PJ, Carlson JR (1999) Odor coding in a model olfactory organ: the Drosophila maxillary palp. J Neurosci 19:4520-4532

De Bruyne M, Foster K, Carlson JR (2001) Odor coding in the Drosophila antenna. Neuron 30:537-552

De Gennaro M, McBride CS, Seeholzer L, Nakagawa T, Dennis EJ, Goldman C, Jasinskiene N, James AA, Vosshall LB (2013) Orco mutant mosquitoes lose strong preference for humans and are not repelled by volatile DEET. Nature 498:487-491

De Moraes CM, Mescher MC, Tumlinson JH (2001) Caterpillarinduced nocturnal plant volatiles repel conspecific females. Nature 410:577-580

Deletre E, Martin T, Campagne P, Bourguet D, Cadin A, Menut C, Bonafos R, Chandre F (2013) Repellent, irritant and toxic effects of 20 plant extracts on adults of the malaria vector Anopheles gambiae mosquito. PLoS ONE 8:12

Deletre E, Chandre F, Barkman B, Menut C, Martin T (2015) Naturally occurring bioactive compounds from four essential oils against Bemisia tabaci whiteflies. Pest Manag Sci. doi:10.1002/ ps.3987

Deletre E, Martin T, Duménil C, Chandre F (2016) DEET and natrural compounds are more effective on Anopheles gambiae resistant strains

Dethier VG (1954) The physiology of olfaction in insects. Ann NY Acad Sci 58(2):139-157

Dickens JC (2006) Plant volatiles moderate response to aggregation pheromone in Colorado potato beetle. J Appl Entomol 130:26-31

Dickens JC, Bohbot JD (2013) Mini review: Mode of action of mosquitoes repellents. Pestic Biochem Phys 106(3):149-155

Dickens JC, Oliver JE, Hollister B, Davis JC, Klun JA (2002) Breaking a paradigm: male produced aggregation pheromone for the Colorado potato beetle. J Exp Biol 205:1925-1933

Ditzen M, Pellegrino M, Vosshall LB (2008) Insect odorant receptors are molecular targets of the insect repellent DEET. Sciences 319:1838-1842

Dogan EB, Ayres JW, Rossignol PA (1999) Behavioural mode of action of DEET: inhibition of lactic acid attraction. Med Vet Entomol 13:97-100

Dunipace L, Meister S, McNealy C, Amrein H (2001) Spatially restricted expression of candidate taste receptors in the Drosophila gustatory system. Curr Biol 11:822-835

Elliott M, Janes NF, Potter C (1978) The future of pyrethroids in insect control. Ann Rev Entomol 23:443-469

Finch S, Collier RH (2012) The influence of host and non-host companion plants on the behavior of pest insects in field crops. Entomol Exp Appl 142:87-96

Foster SP, Harris MO (1997) Behavioral manipulation methods for insect pest-management. Ann Rev Entomol 42:123-146

Foster SP, Denholm I, Thompson R, Poppy GM, Powell W (2005) Reduced response of insecticide resistant aphids and attraction of parasitoids to aphid alarm pheromone; a potential fitness tradeoff. Bull Entomol Res 95:37-46

Fraenkel GS (1959) The 'raison d'être' of secondary plant substances. Science 129:1466-1470

Galizia CG, Rössler W (2010) Parallel olfactory systems in insects: anatomy and function. Ann Rev Entomol 55:399-420

Gibson G, Torr SJ (1999) Visual and olfactory responses of haematophagous Diptera to host stimuli. Med Vet Entomol 13:2-23

Glendinning JL, Valcic S, Timmermann BN (1998) Maxillary palps can mediate taste rejection of plant allelochemicals by caterpillars. J Comp Phys 183:35-43 
Glendinning JI, Brown H, Capoor M, Davis A, Gbedemah A, Long E (2001) A peripheral mechanism for behavioral adaptation to specific "bitter" taste stimuli in an insect. J Neurosci 21:3688-3696

Gomez-Martin A, Duistermars BJ, Frye MA, Matthieu LM (2010) Mechanisms of odor-tracking: multiple sensors for enhanced perception and behavior. Front Cell Neurosci 4:1-15

Grieco J, Achee N, Sardelis M, Chauchan K, Roberts D (2005) A novel high-troughput screening system to evaluate the behavioural response of adult mosquitoes to chemical. J Am Mosquito Contr 21:404-411

Gupta RK, Bhattacharjee AK (2007) Discovery and design of new arthropod/insect repellents by computer-aided molecular modling. In: Debboun M, Frances SP, Strickman D. Insect repellents: principles, methods and uses. CRC Press, Taylor and Francis Group, New York, pp 195-228

Ha TS, Smith DP (2009) Odorant and pheromone receptors in insects. Front cell Neurosci 3(10):55-60

Hallem EA, Carlson JR (2006) Coding of odors by a receptor repertoire. Cell 125:143-160

Hansson BS, Stensmyr MC (2011) Evolution of insect olfaction. Neuron 72:698-711

Heisenberg M (2003) Mushroom body memoir: from maps to models. Nat Rev Neurosci 4(4):266-275

Hemingway J, Hawkes NJ, McCarroll L, Ranson H (2004) The molecular basis of insecticide resistance inmosquitoes. Insect Biochem Mol Biol 34:653-665

Hossaert-McKey M, Bagnères-Urbany AG (2012) Ecologie chimique le language de la nature. France, Le Cherche Midi, Chabreuil A. Lefabvre $\mathrm{V}$

Hougard JM, Martin T, Guillet PF, Coosemans M, Itoh T, Akogbeto M, Chandre F (2007) Preliminary field testing of a long-lasting insecticide-treated hammock against Anopheles gambiae and Mansonia spp. (Diptera: Culicidae) in West Africa. J Med Entomol 44:651-655

Irmisch S, Clavijo McCormick A, Günther J, Schmidt A, Boeckler GA, Gershenzon J, Unsicker SB, Köllner TG (2014) Herbivoreinduced poplar cytochrome P450 enzymes of the CYP71 family convert aldoximes to nitriles which repel a generalist caterpillar. Plant J 80(6):1095-1107

Isman MB (1994) Botanical insecticides and antifeedants: new sources and perspectives. Pestic Res J 849(6):11-19

Isman MB (2006) Botanical insecticides, deterrents, and repellents in modern agriculture and an increasingly regulated world. Ann Rev Entomol 51:45-56

Isono K, Morita H (2010) Molecular and cellular designs of insect taste receptor system. Front cell Neurosci 4:20

Jefferis GS, Marin EC, Stocker RF, Luo L (2001) Target neuron prespecification in the olfactory map of Drosophila. Nature 414(6860):204-208

Jermy T (1990) Prospects of antifeedant approach to pest control-a critical review. J Chem Ecol 16:3151-3166

Jilani G, Saxena RC (1990) Repellent and feeding deterrent effects of turmeric oil, sweetflag oil, neem oil, and a neem-based insecticide against lesser grain borer (Coleoptera: Bostrychidae). J Econ Entomol 83(2):629-634

Junker RR, Klupsch K, Paulus J (2015) Prior exposure to DEET interrupts positive and negative responses to olfactory cues in Drosophila melanogaster. J Insect Behav 28(1):1-14

Kain P, Boyle SM, Tharadra SK, Guda T, Pham C, Dahanukar A, Ray A (2013) Odour receptors and neurons for DEET and new insect repellents. Nature 000:1-8

Kaupp UB (2010) Olfactory signaling in vertebrates and insects: differences and commonalities. Nat Rev Neurosci 11:188-200

Kessler A, Baldwin IT (2001) Defensive function of herbivoreinduced plant volatile emissions in nature. Science 291:2141-2144
Khan ZR, Pickett JA (2004) The "push-pull” strategy for stemborer management: a case study in exploiting biodiversity and chemical ecology. In: Gurr GM, Wratten SD, Altieri MA. ecological engineering for pest management: advances in habitat manipulation for arthropods. CABI, Wallington, pp 155-164

Khan ZR, Chiliswa P, Ampong-Nyarko K, Smart LE, Polaszek A, Wandera J, Mulaa MA (1997a) Utilisation of wild gramineous plants for management of cereal stemborers in Africa. Int J Trop Insect Sci 17:143-150

Khan ZR, Ampong-Nyarko K, Chiliswa P, Hassanali A, Kimani S, lwande WA, Overholt WA, Pickett JA, Smart LE, Woodcock CM (1997) Intercropping increases parasitism of pests. Nature 388:631-632

Kim SH (2013) Insect GPCRs and TRP channels: putative targets for insect repellents. Interdi Bio Central 6-12

Kimani SM, Chhabra SC, Lwande W, Khan ZR, Hassanali A, Pickett JA (2000) Airborne volatiles from Melinis minutiflora P. Beauv, a non-host plot of the two spotted stem borer. J Essent Oils Res 882(12):221-224

Knaden K, Strutz A, Ahsan J, Sachse S, Hansson BS (2012) Spatial representation of odorant valence in an insect brain. Cell 1:392-399

Koul O (2008) Phytochemical and insect control: an antifeedant approach. Crit Rev Plant Sci 27:1-24

Krieger J, Klink O, Mohl C, Raming K, Breer H (2003) A candidate olfactory receptor subtype highly conserved across different insect orders. J Comp Physiol A 189:519-526

Kwon Y, Kim SH, Ronderos DS, Lee Y, Akitake B, Woodward OM, Guggino WB, Smith DP, Montell C (2010) Drosophila TRPA1 channel is required to avoid the naturally occurring insect repellent citronellal. Curr Biol 20:1672-1678

Laissue PP, Reiter C, Hiesinger PR, Halter S, Fischbach KF, Stocker RF (1999) Three-dimensional reconstruction of the antennal lobe in Drosophila melanogaster. J Comp Neurol 405(4):543-552

Lam PYS, Frazier JL (1991) Rational approach to glucose taste chemoreceptor inhibitors as novel insect antifeedants. ACS Symp 443:400-412

Larsson MC, Domingos AI, Jones WD, Chiappe ME, Amrein H, Vosshall LB (2004) Or83b encodes a broadly expressed odorant receptor essential for Drosophila olfaction. Neuron 43:703-714

Leal WS (2007) Molecular-based chemical prospecting of mosquito attractants and repellents. In: Debboun M, Frances SP, Strickman D. Insect repellents: principles, methods and uses. CRC Press, Taylor and Francis Group, New York, pp 229-248

Leal WS (2013) Odorant reception in insects: roles of receptors, binding proteins, and degrading enzymes. Ann Rev Entomol 58:373-391

Lee Y, Kim SH, Montell C (2010) Avoiding DEET through insect gustatory receptors. Neuron 67-61:903

Mac Cain WC, Leach GJ (2007) Repellents used in fabric: the experience of the US military. In: Debboun M, Frances SP, Strickman D. Insect repellents: principles, methods and uses. Taylor and Francis Group, New York, pp 103-110

Malnic B, Hirono J, Sato T, Buck LB (1999) Combinatorial receptor codes for odors. Cell 96(5):713-723

Marella S, Fischler W, Kong P, Asgarian S, Rueckert E, Scott K (2006) Imaging taste responses in the fly brain reveals a functional map of taste category and behavior. Neuron 49:285-295

Marin EC, Jefferis GS, Komiyama T, Zhu H, Luo L (2002) Representation of the glomerular olfactory map in the Drosophila brain. Cell 109(2):243-255

Martel JW, Alford AR, Dickens JC (2005a) Laboratory and greenhouse evaluation oa synthetic host volatile attractant for Colorado potato beetle, Leptinotarsa decemlineata (Say). Agr For Entomol 7:71-78 
Martel JW, Alford AR, Dickens JC (2005b) Synthetic host volatiles increase efficacy of trap cropping system for management of Colorado potato beetle, Leptinotarsa decemlineata (Say). Agr For Entomol 7:79-86

Martin T, Palix R, Kamal A, Deletre E, Bonafos R, Simon S, Ngouajio M (2013) A repellent net as a new technology to protect cabbage crop. J Econ Entomol 106:1699-1706

Martin T, Gogo EO, Saidi M, Kamal A, Deletre E, Bonafos R, Simon S, Ngouajio M (2014) Repellent effect of an alphacypermethrin treated net against the whitefly Bemisia tabaci Gennadius. J Econ Entomol 107:684-690

Matthews RW, Matthews JR (1978) Insect behavior. USA, Wiley, New York

Melcher C, Pankratz MJ (2005) Candidate gustatory interneurons modulating feeding behavior in the Drosophila brain. PLoS Biol 3:e305

Messchendorp L, Smid HM, Van Loon JJA (1998) The role of an epipharyngeal sensillum in the perception of feeding deterrents by Leptinotarsa decemlineata larvae. J Comp Physiol 183:255-264

Miller JR, Cowles RS (1990) Stimulo-deterrent diversion: a concept and its possible application to onion maggot control. J Chem Ecol 16:3197-3212

Miller JR, Siegert PY, Amimo FA, Walker ED (2009) Designation of chemical in terms of the locomotor responses they elicit from insects: an update of Dethier et al. (1960). Ecol Behav.102:2056-2060

Montell C (2009) A taste of the Drosophila gustatory receptors. Curr Opin Neurobiol 19:345-353

Montgomery ME, Nault LR (1977) Comparative response of aphids aphids to the alarm pheromone, (E) $-\beta$ farnesene. Entomol Exp Appl 22(3):236-242

Moore SJ, Debboun M (2007) History of insect repellent. In: Debboun M, Frances SP, Strickman D. Insect repellents: principles, methods and uses. CRC Press, Taylor and Francis Group, New York, 940:3-29

Moore SJ, Lenglet A, Hill N (2007) Plant-based insect repellents. In: Debboun M, Frances SP, Strickman D. Insect repellents: principles, methods and uses. CRC Press, Taylor and Francis Group, New York

Nakagawa T, Sakurai T, Nishioka T, Touhara K (2005) Insect sexpheromone signals mediated by specific combinations of olfactory receptors. Science 307:1638-1642

Nalyana G, Moore CB, Schal C (2000) Integration of repellents, attractants, and insecticides in a push pull strategy for managing the cockroach (Dictyoptera: Blatellidae) populations. J Med Entomol 37:427-434

Narahashi T (1971) Mode of action of pyrethroids. Bull WHO 44:337-345

Nerio LS, Olivero-Verbel J, Stashenko E (2010) Repellent activity of essential oils: a review. Bioresour Technol 101:372-378

Nilsson E, Bengtsson G (2004) Endogenous free fat y acids repel and attract collembolan. J Chem Ecol 30:1431-1443

Nolen JA, Bedoukian RH, Maloney RE, Kline DL (2002) Method, apparatus and compositions for inhibiting the human scent tracking ability of mosquitoes in environmentally defined three dimensional spaces. US Patent No. 6,362,235. Patent issued March 26, 2002

Nordlund DA (1981) Semiochemicals: a review of the terminology. In: Nordlund DA, Jones RL, Lewis WJ. Semiochemicals: their role in pest control. John Wiley and Sons, New York, pp 13-28

Pennetier C, Chabi J, Martin T, Chandre F, Rogier C, Hougard JM, Pages F (2010) New protective battle-dress impregnated against mosquito vector bites. Parasite Vector 3:81

Pettersson J (1970) An aphid sex attractant. Insect Syst Evol 1(1):63-73
Pickett JA, Wadhams LJ, Woodcock CM, Hardie J (1992) The chemical ecology of aphids. Ann Rev 971 Entomol 37:67-90

Pike B, Rice M, Sabine B, Zalucki MP (1987) The push-pull strategybehavioral control of Heliothis. Australian Cotton Grow, MayJuly, pp 7-9

Ramirez GIJ, Logan JG, Loza-Reyes E, Stashenko E, Moores GD (2012) Repellents inhibit P450 enzymes in Stegomyia (Aedes aegypti). PLoS ONE 7:1-8

Ranson H, N'Guessan R, Lines J, Moiroux N, Nkuni Z, Corbel V (2011) Pyrethroid resistance in African anopheline mosquitoes: what are the implications for malaria control? Trends Parasitol 27:91-98

Ratnadass A, Frenandes P, Avelino J (2012) Plant species diversity for sustainable management of crop pests and diseases in agroecosystems: a review. Agron Sust Dev 32:273-303

Rattan RS (2010) Mechanism of action of insecticidal secondary metabolites of plant origin. Crop Prot 29:913-920

Raviv M, Antignus Y (2004) UV radiation effects on pathogens and insect pests of greenhouse-grown crops. Photochem Photobiol 79:219-226

Ray A (2015) Reception of odors and repellents in mosquitoes. Curr Opin Neurobiol 34:158-164

Regnault-Roger C (1997) The potential of botanical essential oils for insect pest control. Int Pest Manag Rev 2:25-34

Regnault-Roger C, Vincent C, Arnason JT (2012) Essential oils in insect control: low-risk products in a high-stakes world. Ann Rev Entomol 57:405-424

REX Consortium (2013) Heterogeneity of selection and the evolution of resistance. Trends Ecol Evol 28:110-118

Rodrigues V, Siddiqi O (1981) A gustatory mutant of Drosophila defective in pyranose receptors. Mol Gen Genet 181:406-408

Sachse S, Galizia CG (2003) The coding of odor-intensivity in the honeybee antennal lobe: local computation optimizes odour representation. Eur J Neurosci 18:2119-2132

Sanford JL, Shields VDC, Dickens JC (2013) Gustatory receptor neuron responds to DEET and other insect repellents in the yellow fever mosquito, Aedes aegypti. Naturwissenschaften 100:269-273

Saxena RC, Khan ZR (1985) Electronically recorded disturbance in feeding behavior of Nephotettix virescens (Homoptera: Cicadellidae) on neem oil-treated rice plants. J Econ Entomol 78:22-226

Schoonhoven LM (1987) What makes a caterpillar eat? The sensory codes underlying feeding behaviour. In: Chapman RF, Bernays EA, Stoffo JG. Advances in Chemoreception and Behavior. Springer, New York, pp 69-97

Schoonhoven LM (1988) Stereoselective perception of antifeedants in insects. In: Ariens EJ, Van Rensen JJS, Welling W. Stereoselectivity of Pesticides: biological and Chemical Problems. Elsevier, Amsterdam, pp 289-302

Schoonhoven LM, Van Loon JJA (1988) Chemoreception and feeding behavior in a caterpillar: towards a model of brain functioning in insects. Entomol Exp Appl 49:123-129

Schoonhoven LM, Van Loon JJA (2002) An inventory of taste in caterpillars: each species its own key. Acta Zool Acad Sci H 48:215-263

Schoonhoven LM, Blaney WM, Simmonds MSJ (1992) Sensory coding of feeding deterrents in phytophagous insects. In: Bernays EA. insect-plant interactions: feeding and oviposition. CRC Press, Boca Raton, pp 59-79

Schrek CE (1977) Techniques for the evaluation of insect repellents: a critical review. Ann Rev Entomol 22:101-119

Séjourné J, Plaçais PY, Aso Y, Siwanowicz I, Trannoy S, Thoma V, Tedjakumala SR, Rubin GM, Tchénio P, Ito K, Isabel G, Tanimoto H, Preat T (2011) Mushroom body efferent neurons responsible for aversive olfactory memory retrieval in drosophila. Nat Neurosci 14-903-910 
Semmelhack JL, Wang JW (2009) Select Drosophila glomeruli mediate innate olfactory attraction and aversion. Nature 459:218-223

Siegert PY, Walker E, Miller JR (2009) Differential behavioral responses of Anopheles gambiae (Diptera: Culicidae) modulate mortality caused by pyrethroid-treated bednets. J Econ Entomolol 102:2061-2071

Silbering AF, Galizia CG (2007) Processing of odor mixtures in the Drosophila antennal lobe reveals both global inhibition and glomerulus-specific interactions. J Neurosci 27(44):11966-11977

Smith HA, McSorley R (2000) Potential of field corn as barrier crop and eggplant as a trap crop for management of Bemisia argentifolii (Homoptera: Aleyrodidae) on common bean in north Florida. Fla Entomol 83:145-158

Steck K, Veit D, Grandy R, Bermudez i, Badia S, Mathews Z, Verschure P, Hansson BS, Knaden M (2012) A high-throughput behavioral paradigm for Drosophila olfaction-the Flywalk. Nat Sci Re. 1031(2):1-9

Stensmyr MC, Dweck HKM, Farhan A, Ibba I, Strutz A, Mukunda L, Linz J, Grabe V, Steck K, Lavista- Llanos S, Wicher D, Sachse S, Knaden M, Becher PG, Seki Y, Hansson BS (2012) A conserved dedicated olfactory circuit for detecting harmful microbes in Drosophila. Cell 151:1345-1357

Sturcow B (1959) Ueber den Geschmackssinn und den Tastinn von Leptinotarsa decemlineata Say (Chrysomelidae). Z Vergl Physiol 42:255-302

Suh GS, Wong AM, Hergarden AC, Wang JW, Simon AF, Benzer S, Axel R, Anderson DJ (2004) A single population of olfactory sensory neurons mediates an innate avoidance behaviour in Drosophila. Nature 431:854-859

Suh E, Bohbot JZ, Zwiebel LJ (2014) Peripheral olfactory signaling in insects. Curr Opin Insect Sci 6:86-92

Syed Z, Leal WS (2008) Mosquitoes smell and avoid the insect repellent DEET. PNAS 36:13598-13603

Tauxe GM, MacWilliam D, Boyle SM, Guda T, Ray A (2013) Targeting a dual detector of skin and $\mathrm{CO}_{2}$ to modify mosquito host seeking. Cell 155:1365-1379

Tawatsin A, Wratten SD, Scott RD, Thavara U, Techadamrongsin Y (2001) Repellency of volatile oils from plants against three mosquito vectors. J Vector Ecol 26:76-82

Temu EA, Maxwell C, Munyekenye G, Howard AFV, Munga S, Avicor SW, Poupardin R, Jones JJ, Allan R, Kleinschimidt I, Ranson H (2013) Pyrethroid resistance in Anopheles gambiae, in Bomi County, Liberia, compromises malaria vector control. PLOS ONE 7:9

Thorne N, Chromey C, Bray S, Amrein H (2004) Taste perception and coding in Drosophila. Curr Biol 14:1065-1079

Thorsteinson AJ (1960) Host selection in phytophagous insects. Ann Rev Entomol 5:193-218

Togni P, Laumann R, Medeiros M, Sujii E (2010) Odour masking of tomatoe volatiles in host plant selection of Bemisia tabaci biotype B. Entomol Exp Appl 136:164-173

Tosh CR, Brogan B. 2014. Control of tomato whiteflies using the confusion effect of plant odours. Agron Sustain Dev 1-11

Touhara K, Vosshall LB (2009) Sensing odorants and pheromones with chemosensory receptors. Ann Rev Physiol 71:307-332

Tsitoura P, Koussis K, Iatrou K (2015) Inhibition of Anopheles gambiae odorant receptor function by mosquito repellents. J Biol Chem 290(12):7961-7972

Turlings TCJ, Gouinguené S, Degen T, Fritzsche-Hoballah ME (2002) The chemical ecology of plant-caterpillar-parasitoid interactions. In: Tscharntke T, Hawkins BA. Multitrophic level interactions. Cambridge University Press, Cambridge, pp 148-173

Unsicker SB, Kunert G, Gershenzon J (2009) Protective perfumes: the role of vegetative volatiles in plant defense against herbivores. Curr Op Plant Biol 12:479-485

Van Mele P, Vayssieres JF, Adandonon A, Sinzogan A (2009) Ant cues affect the oviposition behaviour of fruit flies (Diptera: Tephritidae) in Africa. Physiol Entomol 34:256-261

Vassar R, Chao SK, Sitcheran R, Nunez JM, Vosshall LB, Axel R (1994) Topographic organization of sensory projections to the olfactory bulb. Cell 79:981-991

Vet LE, Lenteren JV, Heymans M, Meelis E (1983) An airflow olfactometer for measuring olfactory responses of hymenopterous parasitoids and other small insects. Physiol Entomol 8(1):97-106

Visser JH (1988) Host-plant finding by insects-orientation, sensory input and search patterns. J Insect Physiol 34:259-268

Vogt RG, Riddiford LM (1981) Pheromone binding and inactivation by moth antennae. Nature 293:161-163

Vosshall LB, Hansson BS (2011) A unified nomenclature system for the insect olfactory coreceptor. Chem Sens 36(6):497-498

Vosshall LB, Stocker RF (2007) Molecular architecture of smell and taste in Drosophilla. Ann Rev Neurosci 30:505-533

Vosshall LB, Wong AM, Axel R (2000) An olfactory sensory map in the fly brain. Cell 102:147-159

Wada-Katsumata A, Silverman J, Schal C (2013) Changes in taste neuron support the emergence of an adaptative behavior in cockroaches. Science 340:972-975

Wang Z, Singhvi A, Kong P, Scott K (2004) Taste representations in the Drosophila brain. Cell 117:981-991

Warthen JD, Morgan ED (1990) Insect feeding deterrents. In: Morgan ED, Mandava NB. CRC Handbook of natural pesticide, Boca Raton, pp 23-134

Webster B, Bruce T, Pickett J, Hardie J (2010) Volatiles functioning as host cues in a blend odor become nonhost cues when presented alone to the black bean aphid. Anim Behav 79:451-457

Weintraub PG (2009) Physical control: an important tool in pest management programs. In: Ishaaya I, Horowitz AR. Biorational control of arthropods pests. Springer Science, Amsterdan

White GB (2007) Terminology of insect repellents, Chapter 2. In: Debboun M, Frances SP, Strickman D. Insect repellents: principles, methods and uses. CRC Press, Taylor and Francis Group, New York

WHO (2002) Scaling-up insecticide-treated netting programs in Africa. WHO/CDS/RBM/2002.43

WHO (2013) Guidelines for efficacy testing of spatial repellent, Control of neglected tropical diseases. WHO pesticide evaluation scheme, p 58

Yadouleton A, Martin T, Padonou G, Chandre F, Asidi A, Djogbenou L, Dabire R, Aikpon R, Boko M, Glitho I, Akogbeto M (2011) Cotton pest management practices and the selection of pyrethroid resistance in Anopheles gambiae population in Northern Benin. Parasite Vector 4:60-69

Yarmolinsky DA, Zuker CS, Ryba NJ (2009) Common sense about taste: from mammals to insects. Cell 139:234-244

Zaim M, Aitio A, Nakashima N (2000) Safety of pyrethroid-treated mosquito nets. Med Vet Entomol 14:1-5 